\title{
МІФОЛОГІЧНИЙ СУБСТРАТ ЖАРГОННОЇ ЛЕКСИКИ (на матеріалі української, російської і польської мов)
}

\author{
ОКСАНА ТАРАН \\ Харківський національний педагогічний університет імені Г. С. Сковороди, \\ Харків - Україна \\ MITOLOGICZNY SUBSTRAT LEKSYKI ŻARGONU \\ OKSANA TARAN \\ Charkowski Narodowy Uniwersytet Pedagogiczny imienia Hryhorija Skoworody, \\ Charków - Ukraina
}

STRESZCZENIE. W artykule przeanalizowano aspekty przejawiania mitologicznego substratu leksyki żargonowej: emocjonalną ekspresywność, zoomorfizm, eufemizację, korelację z binarnymi opozycjami archetypowymi.

\section{MYTHOLOGICAL SUBSTRATE OF JARGON VOCABULARY}

\section{OKSANA TARAN}

Kharkiv H. S. Skovoroda National Pedagogical University, Kharkiv — Ukraine

ABSTRACT. The article focuses on the aspects of the expressive value of mythological jargon vocabulary: emotional expressiveness, euphemisms, correspondence to archetype binary oppositions.

$\mathrm{X}$

арактерною прикметою слов'янських мов XXI століття є їх жаргонізація, про що свідчить підвищений в останні два десятиліття інтерес науковців, який виявився в появі низки грунтовних досліджень із цього питання та словників сленгу, жаргону, арго (в україністиці - Л. Масенко, Л. Ставицька, О. Тараненко, Г. Аркушин, Т. Кондратюк; у русистиці - В. Бондалєтов, М. Грачов, В. Єлістратов, В. Мокієнко, Т. Нікітіна; у болгарській жаргонології - Г. Армянов; у полоністиці - K. Czarnecka, M. Czeszewski, S. Kania). Принагідно тут можна згадати основоположні в галузі соціолінгвістики праці І. Бодуена де Куртене, О. Горбача, В. Даля, Й. Дзендзелівського, В. Жирмунського, Б. Ларіна, Д. Лихачова, Л. Скворцова.

Процес субстандартизації мовлення охоплює не тільки усно-побутову сферу, але й засоби масової інформації, політичний і художній дискурс, публіцистику, естрадне мистецтво. В. Слістратов пояснює такий сплеск ненормативних мовних одиниць викидом надлишкової енергії біосфери в мовлення, що збігається (зумовлений. - О. Т.) з нестабільними періодами в суспільстві ${ }^{1}$. А це спричиняє соціокультурні зрушення та суттєві зміни мовних смаків (О. Селіщев, С. Поліванов, Ю. Сорокін, М. Грачов, В. Костомаров, О. Земська, С. ТерМінасова).

${ }^{1}$ В. С. Елистр атов, Сленг (арго): миф и реальность, [в:] Толковый словарь русского сленга, Москва 2008, с. 9. 
Звичайно, головним жаргононосієм і жаргонопоширювачем є молодь, адже „надлишок енергії спостерігається саме в молодої „популяціі” то через посередництво саме молодіжного жаргонуз до загального жаргону, міського просторіччя й розмовного мовлення потрапляють арготизми - одиниці мовлення закритих соціальних груп, кримінальних субкультур. За свідченням В. Хіміка, приблизно три четвертих від загального обсягу жаргонної лексики молоді складають кримінальні запозичення ${ }^{4}$, причому $78 \%$ арготизмів з побутової лексики загальнокримінального арго, 14 \% - iз тюремного і 8 \% зі спеціалізованих арго 5 . Аналогічну картину спостерігаємо і в українській мові. У зв'язку із цим постають два актуальних питання: по-перше, що лежить в основі такого швидкого поширення жаргонізмів у масах, а по-друге, чи існують спільні елементи в механізмі поширення й функціонування одиниць молодіжного жаргону й арго.

Досліджуючи мовлення злодіїв, Д. Лихачов знаходить у ньому риси первісного примітивізму, що, як видається, співвідносні з міфологічним мисленням. Гіпотетично передбачаємо міфологічний субстрат жаргонної лексики, що сприяє її легкому поширенню. Аналіз словників молодіжного й загального жаргону (сленгу) української (Т. Кондратюк, Л. Ставицька), російської (Т. Нікітіна, В. Слістратов) та польської (M. Czeszewski, S. Kania) мов дав змогу виділити в цій проблемі кілька аспектів.

1. Жаргонна лексика й фразеологія наскрізь пронизані експресивністю й емоційністю. Найбільш показовими в цьому плані є жаргонізми 3 емоційною оцінкою: в українській мові - зашибенно, класно, прикольно, круто, супер, min-mon, кайф, фігня, хріново, галімий, грьобаний, кльовий, офігенний, у російській мові вживаються аналогічні жаргонізми, в польській — super, ekstra, luks, gitny, а також слова, що використовуються у формулах прокляття та виражають емоції: kur, kurna, kurde, kurka wodna, kuchnia. На думку К. Леві-Брюля, емоційний характер є особливістю первісного мислення, тобто мислення нерозчленованого, міфологічного. Д. Лихачов відзначає емоційну експресивність і в арготизмів та пов' язує її з вірою в магію слова, що була притаманна язичникам ${ }^{6}$.

2. Одним із найпродуктивніших способів семантичного творення жаргонізмів є метафоризація, в основі якої - асоціація за аналогією. Асоціація взагалі $\epsilon$ універсальним чинником розвитку й збагачення мови (Й.-Ф. Гербарт, Г. Штейнталь). Шляхом метафоризації утворені жаргонізми-зооніми. В основі зооморфізму лежить анімізм, тут простежуємо зв'язок із найдавнішими міфами. Вірування в одухотворення всієї природи Е. Тайлор уважає першою та головною причиною „перетворення фактів щоденного досвіду на міф”, „ці ідеї спираються на широку філософію природи, щоправда, первісну й грубу, однак сповнену думки й сприйняту цілком реально й серйозно"7. У зооморфізм включаються як неживі предмети або явища (наприклад, у польському молодіжному жар-

\footnotetext{
${ }^{2}$ Там само.

${ }^{3}$ Ми говоримо про мовлення відкритих соціальних груп — жаргон, сленг, їх розмежування тут непринципове.

${ }^{4}$ В. В. Химик, Поэтика низкого, или Просторечие как культурный феномен, СанктПетербург 2000, с. 78.

${ }_{5}^{5}$ М. А. Грачев, Происхождение и функиионирование русского арго, автореф. дис. докт. филол. наук, Санкт-Петербург 1995, с. 24.

${ }^{6}$ Д. С. Лихачев, Черты первобытного примитивизма воровской речи, [в:] Язык и мышление, Москва-Ленинград 1935, т. 3-4, с. 64.

7 Э. Б. Тайлор, Миф и обряд в первобытной культуре, пер. с англ. Д. А. Коропчевского, Смоленск 2000, с. 55.
} 
гоні: koza — велосипед, krowa — пляшка горілки об'ємом 0,75 л, kogut — вогники на дискотеках; світловий сигнал на поліцейській машині, koń - відсоток чистого алкоголю в алкогольному виробі; у російському молодіжному жаргоні: блоха - речовий ринок, змея - потяг; в українському: півень - зачіска ,ірокез”, жаба - заздрість), так і люди.

Авторку цього дослідження зацікавили ті жаргонні зооніми, що відповідають семантичному вектору метафоризації „тварина — людина” й уживаються для характеристики зовнішності людини (укр. крокодил (про дівчину / жінку), карга, жаба, мавпа, криса, кобилка, удав, свиня; рос. конь (про дівчину), крыса, хорёк, жсаба; пол. byk, matpa, kotka, kobra (про людину в окулярах)); їі розумових здібностей (укр. бик, вівия, мавпа, дятел, лошара, лось; рос. лось, страус, бык, дятел; пол. toś, dzięcioł, cap, baran); характеру (укр. коза, криса, жаба, свин, баклан, півень; рос. рыба, козёл, крыса, лось, гусь, баклан, жаба; пол. таһра, toś); сексуальної поведінки й здібностей (укр. кішка, жаба, курка, свиня, жеребецьь, муха; рос. козёл, кукушка, вол, барсук, петух, коза, кобыла; пол. ogier, byk, świnia, matpa), комунікативних особливостей (укр. баклан, кобра; рос. баклан), а також як зневажливі номінації представників чоловічої чи жіночої статі (укр. кінь, козел, коза, курка, телиия /тьола /тьолка /теличка, кобила, вівия, мавnа; рус. рыба, козёл, кукушка, ворона, хорёк, страус, жаба, коза; пол. Łoś, krowa). Як бачимо, один і той самий жаргонізм входить до різних лексико-семантичних груп, що пояснюється загальною тенденцією субстандартної лексики до розмитості, дифузності значень. У цьому зв'язку наведемо спостереження Д. Лихачова щодо кримінального арго: він назвав його „винятковим зразком нестабілізованої та дифузної семантики”, у чому воно близьке до первісної семантики ${ }^{8}$.

Розгляньмо на семному рівні, як саме стилістично нейтральні назви тварин стають жаргонізмами, набуваючи емоційно-експресивних і оцінних конотацій. Семно-компонентний аналіз укр. бик дає змогу виділити такі диференційні експліцитні семи: „великий”, „рогатий”, „самець”, „молодий”, а контексти слововживання виявляють імпліцитні периферійні семи „сильний”, „дикий”, агресивний”, „енергійний”, актуалізація яких і дала поштовх для розвитку переносних значень (порівняймо наведені В. Далем значення похідних від рос. бык слів: быковатылй — „понурий, хто дивиться спідлоба”, бычиться — „дикувати, бути наполегливо й дико сором'язливим на людях, суворитися, дивитися похмуро, упиратися"я). Словники українського жаргону (сленгу) фіксують такі значення українського жаргонізму бик - це „людина, яка віддає перевагу силі перед розумом”, „невисокого розумового рівня, але агресивна, самовпевнена людина" 10 , „фізично сильний чоловік”, „примітивна, обмежена людина, переважно з села"11 (в останньому лексико-семантичному варіанті спостерігаємо протиставлення міста як середовища цивілізованого, високого, інтелектуального та села як джерела нецивілізованого, грубого, неотесаного). Словник польського молодіжного жаргону подає такі значення жаргонізму-зооніма byk: „сильний, добре фізично розвинений парубок, чоловік”, „чоловік, парубок, який веде активне сексуальне життя" ${ }^{2}$. Властива молодіжному мовленню настанова на жарт, мовну гру породжує похідні жаргонізми: наприклад,

${ }^{8}$ Д. С. Лихачев, Указан. работа, с. 70-71.

9 В. И. Даль, Толковый словарь живого великорусского языка: в 4 тт., Москва 2007, т. 1, c. 149.

${ }^{10}$ T. М. Кондратюк, Словник сучасного украӥнського сленгу, Харків 2006, с. 58.

${ }_{11}$ Л. Ставицька, Украӥнський жартон. Словник, Київ 2005, с. 54.

${ }^{12}$ M. Czes zewski, Słownik slangu młodzieżowego, Piła 2001, s. 24. 
від укр. бик-бичок, бичара. Словотвірні елементи, вочевидь, підсилюють експресію. Аналогічні процеси спостерігаємо в польській мові: bykol - те ж саме, що й $b y k^{13}$. Жаргонне значення поширюється й на представниць жіночої статі. Так, в українському жаргоні бичка — „огрядна дівчина з обмеженими розумовими здібностями, переважно з села"14, „дурепа"15.

Простежуємо цікаві етнокультурні паралелі. У давньогерманській лінгвокультурній традиції бик уважався втіленням духовної чистоти, шанувався як божество, був священною твариною (як і корова), символізував безсмертя ${ }^{16}$. Однак, як зауважує Б. Казанський, „уся ця скотарська ідеологія та поезія була чужою слов'янству"17. А в слов'янському бестіарії, за даними міфологічних словників і словників символів (О. Потапенко, М. Дмитренко, О. Бєлова, В. Шуклін), бик - міфічне втілення буйної сили, сильний звір, позначення впертої людини, символ фізичної сили, здоров'я. Отже, можна передбачити розвиток жаргонного значення на основі універсальних асоціацій у межах певної етнокультури. Зооніми в процесі переосмислення за вектором „тварина — людина" набувають негативних оцінних конотацій, що цілком відповідає загальновідомому в лінгвістиці факту переважання пейоративних змін у значенні слова. Щодо прояву зооморфізму в кримінальному арго, то, за спостереженням М. Грачова, зооморфізми не збігаються за значенням з тими, що вживані в байках і казках, оскільки характеризують людину й предмети зовсім 3 інших боків ${ }^{18}$.

3. Ще одним проявом міфологічного мислення $є$ табу, що в мові виявляється через евфемізми. Такими, наприклад, $є$ жаргонізми-зооніми на позначення людей за сексуальними характеристиками: укр. голубий, гей, дятел, півень / пєтух / півник, козел - пасивний / активний гомосексуаліст. У російській мові на позначення цих осіб уживаються жаргонізми дятел, козочка, петух, неповнолітнього гомосексуаліста називають барсук, активну / пасивну лесбіянку - кабан. У польському молодіжному жаргоні сексуального збоченця іменують świnia. Причиною такого вживання зоонімів є мовна гра, з одного боку, та відносна універсальність табу (С. Ульман), — 3 іншого. Б. Успенський указує на табуйованість слів, що „семантично пов'язані з матерщиною, зокрема на позначення геніталій"19. Очевидно, тут має місце зв'язок з давнім фалічним культом. М. Маковський зазначає: „Наскрізним мотивом усіх язичницьких ритуалів була сексуальність, що незмінно мала сакральний, священний характер" 20. Характерно, що в молодіжний жаргон ці слова прийшли 3 кримінального арго.

4. Сучасний молодіжний жаргон вписаний в постмодерну культуру з iі філософією тіла, що, за теорією М. Бахтіна, відповідає „низовій культуpi" — тілесній, конкретній, яку індивід не тільки “переживав", але й утілював. Це протиставлення частин культур корелює 3 архетипною бінарною опозицією „верх — низ”, що на мовному рівні втілені в протиставленні унормовано-

13 Там само.

14 Л. Ст авицька, Зазнач. прачя, с. 55.

15 Т. М. Кондратюк, Зазнач. праия, с. 59.

${ }^{16}$ М. М. Маковский, Язык - миф - культура. Символьл жизни и жсизнь символов, [в:] „Вопросы языкознания”, 1997, № 1, с. 90-91.

${ }^{17}$ Б. В. Казанский, В мире слов, Санкт-Петербург 2006, с. 263.

${ }^{18}$ М. А. Грачев, Русское арго, Нижний Новгород 1997, с. 64.

${ }^{19}$ Б. А. Успенский, Мифологический аспект русской экспрессивной фразеологии, [в:] его же, Избр. трудыл, в 2 т., Язык и культура, Москва 1994, т. 2 , с. 53.

${ }^{20}$ М. М. Маков кий, Семиотика языческих культов (мифопоэтические этюды), [в:] „Вопросы языкознания”, 2002, № 6, с. 74. 
го мовлення як ознаки „верхньої культури” та субстандарного мовлення, характерного для „низової культури”. Ця архетипна бінарна опозиція виявляється і всередині субстандартного (зокрема й жаргонного) мовлення: через актуалізацію лексики табуйованих у традиційній (тобто „верхній”) культурі тем (фізіологічні процеси, сексуальна тема тощо). 3. Фрейд в основі табу вбачає певну заборонену дію, до якої в несвідомому є велика схильність (у давніх народів це заборона торкатися мерців, новонароджених, хворих, жінок у хворобливих станах), причому ці заборони передавалися від покоління до покоління i, як припускає вчений, „організувалися” в майбутніх поколіннях як частина успадкованого психічного багатства, що й пояснює сучасні заборони моралі й звича$\ddot{1 ̈}^{21}$, насамперед і мовні табу.

У жаргоні спостерігаємо вияв як евфемізації (наприклад, укр. поклеїти, давати, полуничка - переосмислене використання літературних слів у жаргонному значенні, сюди слід додати й назви інтимних частин тіла: укр. булки, сілікон, банан; рос. банан, кукуруза, изыпа; пол. koń), так і дисфемізації, що проявляється в уживанні згрубілої, часто вульгарної, але знову ж переосмисленої лексики: укр. сперматозоїд — хлопець, ригалівка - дешевий бар.

5. Жаргон активно реалізує ще одну архетипну бінарну опозицію „свій чужий”, що найяскравіше виявляється в запозичених із арго найменуваннях представників правоохоронних органів: укр. мент, глухар; рос. мент, мусор, свинья; пол. pies, ment. У молодіжному жаргоні зберігається негативна конотація, властива арготизмам, що відображають світоглядну позицію кримінальних субкультур: протиставлення суспільства з його законослухняними членами (,фраєрами”) і представниками закону (,ментами”) — антисуспільству 3 його системою правил („поняттями”), його членами („кентами”) як протиставлення чужого своєму. Ця опозиція виявляється і в жаргонних номінаціях осіб за національністю або расовою приналежністю: в українській мові представників негроїдної раси іронічно називають шоколадка, зефір, блек, лумумба; кавказьких народів - урюк, арік, хачик, азік, азер; азіатських - чурка, косий, фазан; євреїв іменують як сарочка, аїд, маца; росіян - запроданецьь, лапотник, раша; білорусів - сябр, бульба; поляків - пшек, псек; німців - шпрехен, дойч, герман; американців - макдональдс, америкос; італійців - мафіозі, лапша тощо.

Отже, аналіз жаргонної лексики молодіжного мовлення трьох слов'янських мов, з яких дві близькоспоріднені, виявив:

1) спільні значеннєві елементи, особливо серед зооморфічних жаргонізмів. Це пояснюється тим, що жаргонізми-зооніми, з одного боку, є продуктом конкретно-образного мислення, а з іншого, - мають глибокий, хоча й неусвідомлений зв'язок із міфом і ритуалом;

2) реалізацію архетипних бінарних опозицій. Окрім проаналізованих, окремий інтерес становить опозиція „жіночий — чоловічий”, що посідає головне місце в наборі семіотичних опозицій моделі світу;

3) кореляцію молодіжного жаргону й кримінального арго у функціональному призначенні: табуювання, евфемізація, вираження максимальної експресії мінімальним набором мовних засобів, що спричиняє розмитість значення.

${ }^{21}$ 3. Фрейд, Тотем и табу, пер. с нем. М.В. Вульфа, Санкт-Петербург 2010, с. 45, 59-60. 